\title{
Blood Pressure Phenotypes in Treated Hypertensive Patients in Summer and Winter: Focus on Masked Uncontrolled Hypertension. Part 1: Blood Pressure Phenotypes Prevalence
}

\author{
Marina I. Smirnova1*, Vladimir M. Gorbunov', Sergey A. Boytsov², Michail M. Loukianov¹, \\ Anna M. Kalinina1, Dmitriy A. Volkov1, Alexander D. Deev1, Yana N. Koshelyaevskaya1, \\ Ekaterina N. Belova1 \\ 1 National Medical Research Center for Preventive Medicine. Petroverigsky per. 10, Moscow, 101990 Russia \\ 2 National Medical Research Center for Cardiology. Tretya Cherepkovskaya ul. 15a, Moscow, 121552 Russia
}

\begin{abstract}
Background. The seasonal variability of blood pressure (BP) and cardiovascular morbidity and mortality motivates researchers to search for the new approaches of the antihypertensive treatment ( $\mathrm{AHT}$ ) efficacy assessment, including the analysis of interrelation between clinic and ambulatory $\mathrm{BP}$, i.e. BP phenotypes.

Aim. To evaluate the prevalence of BP phenotypes in treated hypertensive outpatients both in winter and summer.

Material and methods. Hypertensive patients under regular AHT with available data of clinic BP and 24-hour BP monitoring both in winter and summer seasons ( $n=477$ ) were selected from a outpatient database with clinic BP $<160 / 100 \mathrm{~mm} \mathrm{Hg}(n=1762)$. The BP threshold values from current guidelines were used for the BP phenotypes definition. The "controlled hypertension" phenotype was detected when clinic and ambulatory BP levels were less than threshold values, the "uncontrolled hypertension" - when both levels exceeded the thresholds, the "white coat hypertension (WCH) in treated patients" - when clinic BP was only increased, the "masked uncontrolled hypertension" phenotype was ascertained if ambulatory BP was only elevated.

Results. The study included 232 patients examined in Ivanovo (a relatively cold region; mean age $53.5 \pm 9.3$ years; $28 \%$ men; clinic BP $121.7 \pm 7.9$ $\mathrm{mm} \mathrm{Hg}$; mean duration of hypertension $4.6 \pm 6.3$ years) and 245 patients from Saratov (a relatively hot region; mean age $58.3 \pm 10.6$ years; $56.3 \%$ men; clinic BP $127.5 \pm 14.9 \mathrm{mmHg}$; mean duration of hypertension $9.2 \pm 9.2$ years; $p<0.0001$ ). In the Ivanovo cohort, ratio of BP phenotypes in summer and winter did not differ; the "masked uncontrolled hypertension" phenotype prevailed $(62.1 \%$ and $63.8 \%$ in winter and summer, respectively); AHT was effective in $27.6 \%$ and $29.7 \%$ of the patients in winter and summer, respectively. The prevalence of other phenotypes was low: uncontrolled hypertension $-9.5 \%$ in winter and $6.0 \%$ in summer; WCH in treated patients - less than $1 \%$ in both seasons. The prevalence of BP phenotypes in the patients examined in Saratov differed in winter and summer $\left(\chi^{2}=18.127, p<0.0001\right)$; the "masked uncontrolled hypertension" phenotype rate was higher in summer than in winter $(50.2 \%$ and $32.2 \%$, respectively); the rates of other phenotypes were higher in winter: uncontrolled hypertension $-38.8 \%$ and $27.8 \%$, controlled hypertension $-25.3 \%$ and $20.8 \%$, WCH $-3.7 \%$ and $1.2 \%$ in winter and summer, respectively. Conclusion. We have found no seasonal changes in BP phenotypes prevalence in relatively younger hypertensive patients in a relatively cold region. The "masked uncontrolled hypertension" phenotype was predominant ( $>60 \%)$ in this region. In contrast, the cohort of relatively older patients with longer hypertension history examined in a relatively warmer region revealed significantly higher rate of masked uncontrolled hypertension in summer (50.2\%) while prevalence of all other phenotypes - in winter.
\end{abstract}

Keywords: hypertension, ambulatory blood pressure monitoring, blood pressure phenotypes, masked hypertension, masked uncontrolled hypertension, seasonal variability.

For citation: Smirnova M.I., Gorbunov V.M., Boytsov S.A., Loukianov M.M., Kalinina A.M., Volkov D.A., Deev A.D., Koshelyaevskaya Y.N., Belova E.N. Blood Pressure Phenotypes in Treated Hypertensive Patients in Summer and Winter: Focus on Masked Uncontrolled Hypertension. Part 1: Blood Pressure Phenotypes Prevalence. Rational Pharmacotherapy in Cardiology 2017;13(5):578-589. DOI: 10.20996/1819-6446-2017-13-5-578-589

\footnotetext{
Фенотипы артериального давления в летний и зимний период у больных артериальной гипертонией: внимание на скрытую неэффективность антигипертензивной терапии. Часть 1: частота фенотипов

Марина Игоревна Смирнова1*, Владимир Михайлович Горбунов¹, Сергей Анатольевич Бойцов², Михаил Михайлович Лукьянов 1 ,

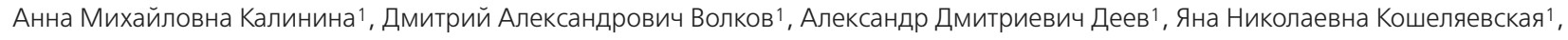
Екатерина Николаевна Белова ${ }^{1}$

1 Национальный медицинский исследовательский центр профилактической медицины

Россия, 101990, Москва, Петроверигский пер., 10

2 Национальный медицинский исследовательский центр кардиологии

Россия, 121552, Москва, ул. 3-я Черепковская, 15а
}

Сезонная вариабельность показателей артериального давления (АД) и сердечно-сосудистой заболеваемости и смертности заставляет искать новые подходы к оценке эффективности антигипертензивной терапии (АГТ), в том числе с учетом соотношения показателей клинического и амбулаторного АД, т.е. фенотипов АД.

Цель. Изучить частоту фенотипов АД в зимний и летний периоды у амбулаторных пациентов, получающих регулярную АГТ.

Материал и методы. Из базы данных амбулаторных пациентов с клиническим АД<160/100 мм рт.ст. (n=1762), отобраны больные артериальной гипертонией (АГ) с наличием регулярной АГТ и показателей клинического АД и суточного мониторирования АД как в зимний, так и летний период ( $\mathrm{n}=477)$. Для определения фенотипа использованы пороговые значения из актуальных рекомендаций. Если оба показа- 
теля АД были ниже пороговых значений, то фенотип классифицировали как «эффективная АГТ», если оба показателя АД превышали порог - «неэффективная АГТ», если было повышено только клиническое АД - «гипертония белого халата (ГБХ) на лечении», если было повышено только амбулаторное АД, то фенотип определяли как «скрытая неэффективность лечения АГ» (СНЛ АГ).

Результаты. Включено 232 пациента, обследованных в Иваново (относительно холодный регион; возраст 53,5 $\pm 9,3$ лет, мужчин 28\%, кли-

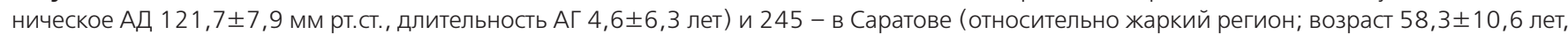

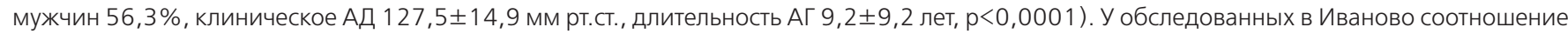
фенотипов АД летом и зимой не различалось, преобладал фенотип со СНЛ АГ (62,1\% зимой и 63,8\% летом), эффективно лечились 27,6\% и 29,7\% пациентов зимой и летом, соответственно. Количество пациентов с неэффективной АГТ ( $9,5 \%$ зимой и 6,0\% летом) и ГБХ на лечении (<1\% в оба сезона) было невелико. У обследованных в Саратове соотношение фенотипов АД зимой и летом различалось $\left(\chi^{2}=18,127\right.$, $\mathrm{p}<0,0001)$ : частота СНЛ АГ была летом выше (50,2\%), чем зимой (32,2\%); частота остальных фенотипов была выше зимой - неэффективной АГТ 38,8\% и 27,8\%, эффективной АГТ - 25,3\% и 20,8\%, ГБХ на лечении - 3,7\% и 1,2\% зимой и летом, соответственно.

Заключение. В нашем исследовании в когорте пациентов более молодого возраста в относительно холодном регионе отсутствовала выраженная сезонная динамика фенотипов АД, и преобладал фенотип с СНЛ АГ (>60\%). В когорте пациентов более старшего возраста с бо́льшим «стажем» АГ, обследованных в более теплом регионе, частота СНЛ АГ значимо выше была летом (50,2\%), частота остальных фенотипов зимой.

Ключевые слова: артериальная гипертония, суточное мониторирование артериального давления, фенотипы артериального давления, скрытая артериальная гипертония, скрытая неэффективность лечения артериальной гипертонии, сезонная динамика.

Для цитирования: Смирнова М.И., Горбунов В.М., Бойцов С.А., Лукьянов М.М., Калинина А.М., Волков Д.А., Деев А.Д., Кошеляевская Я.Н., Белова Е.Н. Фенотипы артериального давления в летний и зимний период у больных артериальной гипертонией: внимание на скрытую неэффективность антигипертензивной терапии. Часть 1: частота фенотипов. Рациональная фармакотерапия в кардиологии 2017;13(5): 578-589. DOI: 10.20996/1819-6446-2017-13-5-578-589

*Corresponding Author (Автор, ответственный за переписку): msmirnova@gnicpm.ru

Received / Поступила: 31.08.2017

Accepted / Принята в печать: 12.09.2017

Recent years the concept of "blood pressure (BP) phenotype" is used with increasing frequency. Works of $1990^{\text {th }}$ - early $2000^{\text {th }}$ years used this term with regard to such types of hypertension as isolated nocturnal, systolic or diastolic hypertension, hypertension with increased BP variability or hypertension with individual characteristics of BP diurnal pattern (dipper, non-dipper etc.) [1]. Later BP phenotype was understood as clinic (office) and ambulatory measurements ratio [2]. Four BP phenotypes are distinguished: normotension, white coat hypertension (WCH), masked hypertension and sustained hypertension. This term is seemed to be eligible (especially in cases of WCH and masked hypertension) as each of the types has peculiar characteristics including social-demographic and clinical patients' features [3-6]. Besides, a number of studies had proved prognostic value of unfavorable BP phenotypes in respect of fatal and non-fatal cardiovascular events $[3,7]$. One can suppose that further studies will allow to determine some genetic markers of BP phenotypes, in the first place of those linked to psychological and behavioral features of patients.

The similar four BP phenotypes are also determined in patients under antihypertensive treatment $(\mathrm{AHT})$ (Fig. 1):

- normotension in treated patients (optimal AHT effect with target clinic and ambulatory BP levels achievement),
В последние годы в научной литературе все чаще используется понятие «фенотип артериального давления» (АД). Авторы работ 1990-х-начала 2000-х гг. использовали упомянутый термин применительно к таким вариантам артериальной гипертонии (АГ), как изолированная ночная, систолическая или диастолическая АГ, АГ с повышенной вариабельностью АД, или АГ с индивидуальной характеристикой суточного профиля АД (dipper, non-dipper и др.) [1]. Позже под фенотипом АД стали понимать преимущественно соотношение показателей клинического (офисного) и амбулаторного измерений [2]. Выделяют 4 фенотипа АД: нормотония, гипертония белого халата (ГБХ), скрытая АГ и устойчивая АГ. Использование данного термина (особенно в отношении ГБХ и скрытой АГ) представляется правомочным, поскольку существует комплекс основных характеристик каждого из них, включающий социально-демографические и клинические особенности пациентов [3-6]. Кроме того, в ряде исследований доказана прогностическая значимость неблагоприятных фенотипов АД в отношении фатальных и нефатальных сердечно-сосудистых событий $[3,7]$. Можно предполагать, что дальнейшие исследования позволят определить и некоторые генетические маркеры фенотипов АД, в первую очередь, взаимосвязанные с психологическими и поведенческими особенностями пациентов.

у больных, получающих антигипертензивную терапию (АГТ), также выделяют 4 аналогичных фенотипа АД (рис. 1):

• нормотония на лечении (оптимальный эффект АГ с достижением целевых значений клинического и амбулаторного АД) 


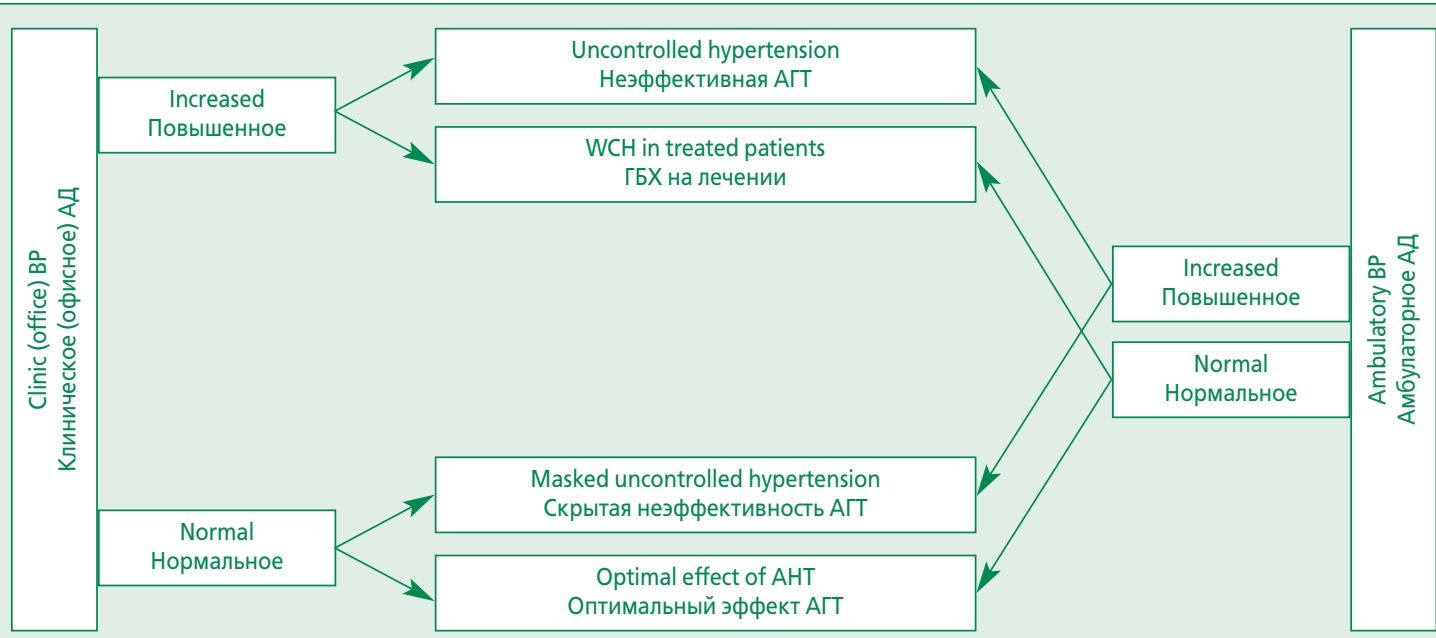

$\mathrm{BP}$ - blood pressure, AHT - antihypertensive treatment, WCH - white coat hypertension

АД - артериальное давление, АГТ - антигипертензивная терапия, ГБХ - гипертония белого халата

Figure 1. BP phenotypes in patients received antihypertensive treatment

Рисунок 1. Фенотипы АД у больных, получающих антигипертензивную терапию

- masked uncontrolled hypertension (isolated increased ambulatory BP with target clinic BP level) [8],

- WCH in treated patients (ambulatory BP target le-vel is only achieved),

- Uncontrolled hypertension (both clinic and ambulatory BP levels keep to be elevated).

Masked uncontrolled hypertension may cause the most difficulties in hypertension diagnostics as normal clinic BP values give the impression of false wellbeing. At that risk of cardiovascular events including fatal ones in masked uncontrolled hypertension is as high as in overt uncontrolled hypertension $[3,4,7]$. It is not by chance that diagnostics of BP phenotypes connected with the "white coat" phenomenon and with the masked hypertension phenomenon is now considered the main indication for the BP 24-hour monitoring $[3,4]$.

Evaluating of seasonal BP variability is the other actual problem in cardiology. The most works dealt with this problem evaluated both office and ambulatory BP but simultaneous estimation of these indices, i.e. BP phenotypes, was not performed. However such estimation is particularly logical, which includes patients received antihypertensive drugs. According to results of many studies levels of both clinic and ambulatory BP are on an average higher in winter season [9-13]. The highest level of cardiovascular mortality is also coincides with cold season [14-20]. This had been also confirmed by the studies performed at the National Medical Research Center for Preventive Medicine (NMRC PM) [19-21]. One of these studies had demonstrated excessive cardiovascular morbidity in Ivanovo in winter - the region with relatively low ambient temperature as compared to some oth-
- скрытая неэффективность лечения АГ (изолированное повышение амбулаторного АД при целевом уровне клинического - masked uncontrolled hypertension [8])

- ГБХ на лечении (достигнут целевой уровень только амбулаторного АД)

- неэффективная АГТ (уровни клинического и амбулаторного АД остаются повышенными).

Наибольшие трудности в диагностике может вызывать скрытая неэффективность лечения АГ, поскольку нормальные значения клинического АД создают впечатление ложного благополучия. В тоже время риск сердечно-сосудистых событий, в том числе фатальных, при скрытой неэффективности лечения АГ так же высок, как и при «явно» неэффективной АГТ $[3,4,7]$. Не случайно диагностика фенотипов АД, связанных как с феноменом «белого халата» ("white coat" phenomenon), так и со скрытой АГ (masked phenomena), признана в настоящее время основным показанием к суточному мониторированию АД (СМАД) $[3,4]$.

Другой актуальной проблемой кардиологии является изучение сезонной вариабельности АД. В большинстве работ на эту тему проводилось измерение как офисного, так и амбулаторного АД, но совместная оценка данных показателей, т.е. фенотипов АД, не изучалась, хотя представляется весьма логичной, в том числе у пациентов, принимающих антигипертензивные препараты. Согласно результатам многих исследований уровень и клинического, и амбулаторного АД в зимний период в среднем выше [9-13]. Также именно в холодное время года отмечается наибольший уровень сердечно-сосудистой смертности [14-20]. Это подтверждают и исследования, выполненные в НМИЦ ПМ [19-21]. Одно из них продемонстрировало избыточную сердечнососудистую заболеваемость зимой в Иваново [20], регионе с относительно низкой температурой окружающей среды по сравнению с некоторыми другими регионами Рос- 
er regions of the Russian Federation (RF) [20]. Patients of the same region had revealed the tendency for masked hypertension as one of our previous works demonstrated [13]. This allows to suppose that masked hypertension contributes to the seasonal pattern of cardiovascular morbidity and mortality rates. Surely, different aspects of seasonal BP variability demand further investigation. Discussion of this issue from the perspective of BP phenotypes theory is also seemed to be rather important.

The aim of the study was to estimate incidence rates of BP phenotypes in patients under regular antihypertensive treatment in winter and summer seasons.

\section{Material and methods}

We used a database of the "Seasonal changes in hemodynamic parameters in patients with controlled arterial hypertension and high normal BP in two regions of the RF with different climatic characteristics" study, which was developed in the NMRC PM in 2012-2014 years ( $n=1762$; the detailed protocol of the study was published earlier [22]). The study enrolled outpatients aged 40-79 years with clinic $B P<160 / 100 \mathrm{~mm} \mathrm{Hg}$. The patients were referred to the Ivanovo Cardiologic Center and to the Research Institute for Cardiology of the Saratov State Medical University from outpatient clinics of an according region. In this work we used the two main criteria for the patients selection:

1) regular antihypertensive treatment with one or more preparations during more than 2 weeks,

2) availability of clinic BP measurements and 24-hour BP monitoring results both in winter and summer seasons.

Exclusion criteria were the follows: night work pattern or night duties presence; inclination of a patient to change a treatment by himself (according to information provided by a patient or to a doctor's opinion or by medical documents data); heart rhythm and cardiac conduction disturbances which impact 24-hour BP monitoring results (for example, atrial fibrillation) and implanted electric pacemaker as well; history of a stroke, transient ischemic attack or myocardial infarction within 6 months before the enrolling into the study; acute diseases or exacerbation of chronic ones (for example ulcer disease, dorsopathy and others); class III obesity (body mass index $>39.9 \mathrm{~kg} / \mathrm{m}^{2}$ ); pregnancy, lactation.

Measurements of clinic BP by the automatic tonometer (OMRON 705 IT), the 24-hour BP monitoring (the BPLab device, OOO Petr Telegin, Nizhny Novgorod, Russia), anthropometry and a conventional examination with history taking were performed twice with 6 -month interval (in winter and in summer). Patients were enrolled both in winter and summer seasons. сийской Федерации. У пациентов этого же региона в одной из наших предыдущих работ отмечена тенденция к скрытой АГ [13], это позволяет предполагать, что скрытая АГ вносит свой «вклад» и в сезонную динамику показателей сердечно-сосудистой заболеваемости и смертности. Безусловно, различные аспекты сезонной вариабельности АД нуждаются в дальнейшем изучении. Представляется весьма важным рассмотрение этого вопроса и с позиций теории фенотипов АД.

Целью представленного исследования стала оценка частоты фенотипов АД в зимний и летний периоды у пациентов, получающих регулярную антигипертензивную терапию.

\section{Материал и методы}

Была использована база данных исследования «Сезонные изменения гемодинамических параметров у больных с контролируемой артериальной гипертонией и высоким нормальным артериальным давлением в двух регионах Российской Федерации с различными климатическими характеристиками», созданная в НМИЦ ПМ в 2012-2014 гг. ( $n=1762 ;$ подробный протокол исследования опубликован ранее [22]). В исследование включали амбулаторных пациентов в возрасте 40-79 лет с клиническим АД<160/100 мм рт.ст., пациенты направлялись в ОБУЗ «Кардиологический диспансер» г. Иваново Центрального Федерального округа и НИИ кардиологии Саратовского государственного медицинского университета Приволжского Федерального округа из поликлиник соответствующего региона. В представленный здесь анализ отбирались сведения о пациентах по двум основным критериям:

1. наличие регулярной АГТ одним или более антигипертензивными препаратами в течение от 2-х нед;

2. наличие клинических измерений АД и результатов СМАД как в зимний, так и летний период.

Критериями невключения были: ночной график работы пациента или наличие ночных смен; склонность пациента самостоятельно менять лечение АГ (со слов пациента или по мнению врача, данным медицинской документации); нарушения ритма сердца и проводимости (например, фибрилляция предсердий), влияющие на результаты СМАД, а также имплантированный электрокардиостимулятор; перенесенный мозговой инсульт, транзиторная ишемическая атака или инфаркт миокарда в пределах 6 мес до даты включения в исследование; острые заболевания и обострения хронических заболеваний (например, язвенной болезни, дорсопатии и др.) ; ожирение III степени (индекс массы тела >39,9 кг/м²); беременность, лактация.

Всем пациентам проводились измерения клинического АД автоматическим тонометром (OMRON 705 IT), СМАД (прибор BPLab OOO «Петр Телегин», Нижний Новгород, Россия), антропометрия и стандартное обследование со сбором анамнеза дважды с интервалом 6 мес (зимой и летом). Пациентов включали в исследование как в зимний, так и в летний период. 
Table 1. Threshold BP levels (in accordance to the ESH/ESC and RSC Guidelines [3,23])

Таблица 1. Пороговые уровни АД (по Рекомендациям ESH/ESC, BHOK [3,23])

\begin{tabular}{|c|c|c|c|}
\hline $\begin{array}{l}\text { Category of blood pressure } \\
\text { Категория артериального давления }\end{array}$ & $\begin{array}{l}\text { SBP } \\
\text { CAД }\end{array}$ & & $\begin{array}{l}\text { DBP } \\
\text { ДАД }\end{array}$ \\
\hline $\begin{array}{l}\text { Office, mm Hg } \\
\text { Офисное, мм рт.ст. }\end{array}$ & $\geqslant 140$ & $\begin{array}{l}\text { and/or } \\
\text { и/или }\end{array}$ & $\geqslant 90$ \\
\hline \multicolumn{4}{|l|}{$\begin{array}{l}\text { Ambulatory, mm Hg } \\
\text { Амбулаторное, мм рт.ст. }\end{array}$} \\
\hline $\begin{array}{l}\text { Daytime (wakeful state) } \\
\text { Дневное (бодрствование) }\end{array}$ & $\geqslant 135$ & $\begin{array}{l}\text { and/or } \\
\text { и/или }\end{array}$ & $\geqslant 85$ \\
\hline $\begin{array}{l}\text { Nighttime (sleeping) } \\
\text { Ночное (сон) }\end{array}$ & $\geqslant 120$ & $\begin{array}{l}\text { and/or } \\
\text { и/или }\end{array}$ & $\geqslant 70$ \\
\hline $\begin{array}{l}\text { 24-hour } \\
\text { Суточное }\end{array}$ & $\geqslant 130$ & $\begin{array}{l}\text { and/or } \\
\text { и/или }\end{array}$ & $\geqslant 80$ \\
\hline
\end{tabular}

Table 1 presents threshold values used for BP phenotype assessment. If values of clinic BP and at least one in 3 of ambulatory BP variants (the 24-h BP mean, daytime mean, nighttime mean) fell into a category of increased BP a patient was referred to the "uncontrolled hypertension" phenotype (ineffective antihypertensive treatment). If values of clinic BP and of all 3 ambulatory BP variants did not exceed thresholds a patient was referred to the "controlled hypertension" phenotype (optimal AHT). Increase in at least one of 3 ambulatory BP types at normal clinic BP was considered the "masked uncontrolled hypertension". Increased clinic BP at normal values of all three types of ambulatory BP was considered the WCH. For example, a patient's BP phenotype was classified as the "masked uncontrolled hypertension" when at target clinic BP ( $<140$ and $90 \mathrm{~mm} \mathrm{Hg}$ ) the mean daytime ambulatory systolic BP (SBP) was $\geqslant 135 \mathrm{~mm} \mathrm{Hg}$ and/or the mean diastolic BP (DBP) was $\geqslant 85 \mathrm{~mm} \mathrm{Hg}$. Time span from 08:00 till 21:59 hours was regarded as daytime (wakeful state), 0:00-5:59 hours - as nighttime.

\section{Statistical analysis}

The data were analyzed using the «SPSS, v21» software application (IBM Inc., the USA). The descriptive statistics was used: assessment of incidence rates of the studied indices, analysis of mean values, standard deviations and errors. Quantitative variables distribution was analyzed for compliance with the normal law. Qualitative variables were assessed by the correlation analysis (the Pearson and Spearman correlations). For estimation of significance of differences in quantitative variables the ANOVA dispersion analysis was used. Indices were presented as mean values $(\mathrm{M})$ with respective standard deviation (SD). The differences were considered statistically significant at $p<0.05$.
Пороговые значения, использованные для определения фенотипа АД, представлены в табл. 1. Если значения клинического АД и хотя бы одного из 3-х вариантов амбулаторного АД (среднесуточное, среднедневное, ночное) подпадали под категорию повышенного, пациент относился к фенотипу с неэффективной АГТ. Если значения клинического и все 3 варианта амбулаторного АД не превышали пороговые значения, пациента относили к фенотипу с оптимальным эффектом АГТ. Скрытой неэффективностью лечения АГ считали повышение хотя бы одного из 3-х вариантов амбулаторного АД при нормальном клиническом АД; ГБХ на лечении определяли как повышенный уровень клинического АД при нормальных значениях всех 3-х вариантов амбулаторного АД. Например, если при нормальном уровне клинического АД ( $<140$ и 90 мм рт.ст.) среднедневной уровень амбулаторного систолического АД (САД) был $\geqslant 135$ мм рт.ст. и/или диастолического АД (ДАД) был $\geqslant 85$ мм рт.ст., фенотип АД пациента классифицировали как скрытая неэффективность лечения АГ. Дневным периодом (период бодрствования) считали время суток с 08:00 до 21.59, ночным - с 00:00 до 05:59.

\section{Статистический анализ}

Обработка данных проводилась с помощью программы «SPSS, v21» (IBM Inc., CШA). Была использована описательная статистика: оценка частот изучаемых показателей, анализ средних величин, стандартных отклонений и ошибок. Для количественных переменных проводился анализ соответствия распределения нормальному закону. Для анализа качественных переменных проводился корреляционный анализ (корреляции Пирсона, Спирмена). Для оценки достоверности различий количественных переменных использовался дисперсионный анализ (ANOVA). Показатели приведены в виде средних величин (M) с соответствующим стандартным отклонением (SD). Различия считали статистически значимыми при уровне значимости $p<0,05$. 
Table 2. Basic characteristics of the patients at including in the study

Таблица 2. Основные характеристики пациентов при включении в исследование

\begin{tabular}{|c|c|c|c|}
\hline Parameters / Параметр & $\begin{array}{l}\text { Both regions / Оба региона } \\
\qquad(n=477)\end{array}$ & $\begin{array}{c}\text { Ivanovo / Иваново } \\
(n=232)\end{array}$ & $\begin{array}{c}\text { Saratov / Саратов } \\
(n=245)\end{array}$ \\
\hline Male sex, \% / Мужской пол, \% & 42.6 & 28.0 & $56.3^{* *}$ \\
\hline Age, years / Возраст, лет & $55.9 \pm 10.2$ & $53.5 \pm 9.3$ & $58.3 \pm 10.6^{* *}$ \\
\hline $\mathrm{BMI}, \mathrm{kg} / \mathrm{m}^{2} / \mathrm{UMT}, \mathrm{kr} / \mathrm{M}^{2}$ & $28.3 \pm 4.4$ & $28.6 \pm 4.3$ & $28.0 \pm 4.5$ \\
\hline Smoking, \% / Курение, \% & 25.5 & 20.2 & 30.6 \\
\hline Salt consumption $\geqslant 6.0 \mathrm{~g} /$ day, \% / Потребление соли $\geqslant 6,0$ г/сутки, \% & 52.9 & 67.2 & $39.3^{* *}$ \\
\hline Hypertension history, years / Длительность АГ, лет & $6.9 \pm 8.3$ & $4.6 \pm 6.3$ & $9.2 \pm 9.2^{* *}$ \\
\hline Clinic SBP, mm Hg / Клиническое САД, мм рт.ст. & $124.6 \pm 12.3$ & $121.7 \pm 7.9$ & $127.5 \pm 14.9 * *$ \\
\hline Clinic DBP, mm Hg / Клиническое ДАД, мм рт.ст. & $74.9 \pm 8.9$ & $74.4 \pm 7.2$ & $75.6 \pm 10.3$ \\
\hline $\begin{array}{l}\text { Data are presented as } \mathrm{M} \pm \mathrm{SD} \text {, unless indicated otherwise } \\
\text { **p<0.01, }{ }^{* * *} \leqslant \leqslant 0.0001 \text { as compared to the similar index in Ivanovo } \\
\text { Данные представлены в виде } \mathrm{M} \pm \mathrm{SD} \text {, если не указано иное } \\
{ }^{* *} \text { p }<0,01,{ }^{* * *} p \leqslant 0,0001 \text { по сравнению с аналогичным значением в Иваново }\end{array}$ & & & \\
\hline
\end{tabular}

Table 3. Phenotypes and levels of BP in patients examined in Ivanovo in winter and in summer $(n=232)$

Таблица 3. Фенотипы и показатели АД зимой и летом у пациентов, обследованных в Иваново $(n=232)$

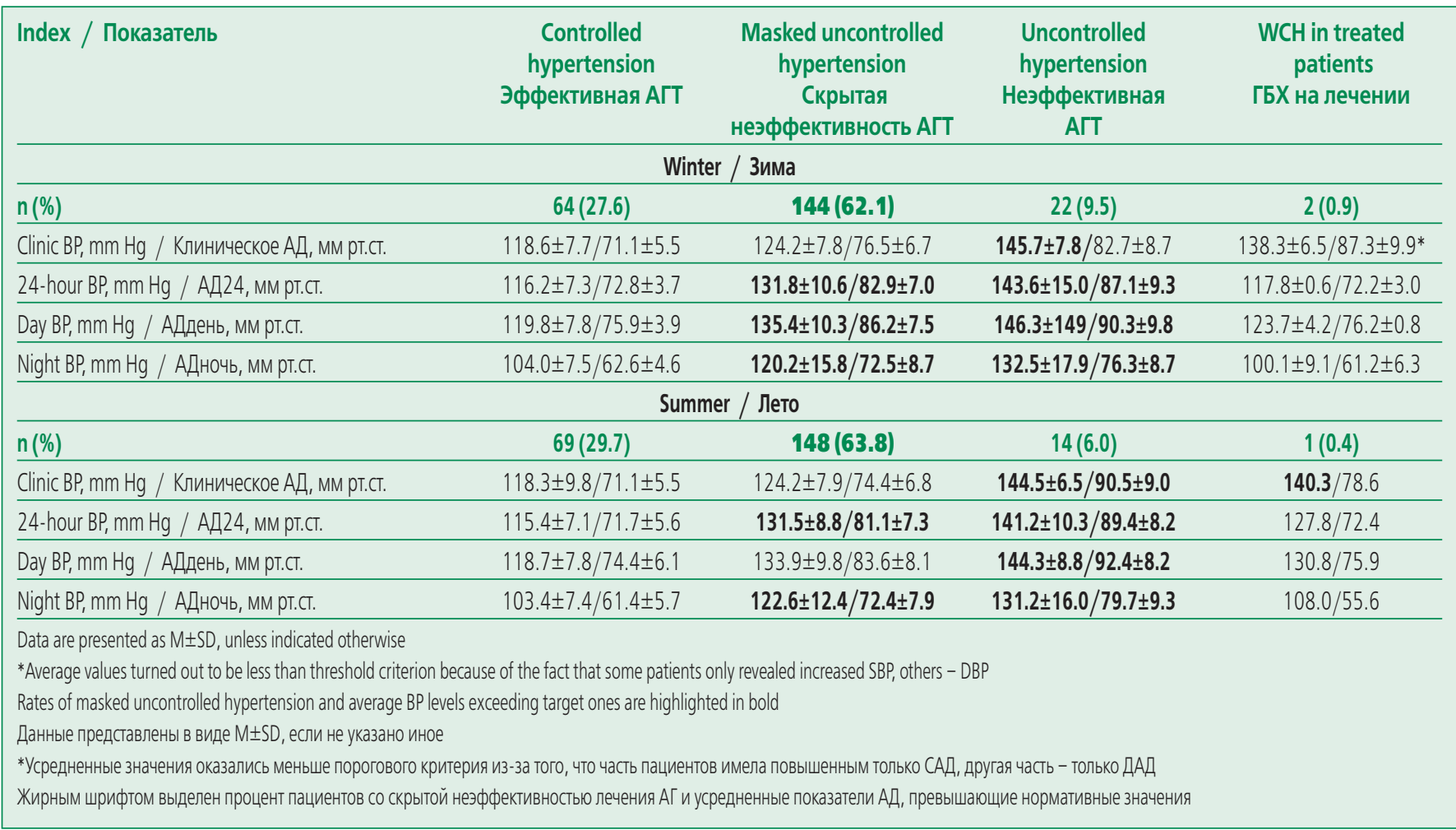

\section{Results}

A total of 477 hypertensives who were receiving regular antihypertensive treatment matched the criteria of the study: 232 were examined in Ivanovo and 245 - in Saratov. The comparative analysis revealed significant differences between the patients of the two regions in the main characteristics (sex, age and some others; Table 2). Clinic BP in the both groups on an average achieved target levels and was even about optimal, especially in patients examined in Ivanovo (Table 2).

\section{Результаты}

Всего критериям исследования соответствовало 477 пациентов с АГ, получавших регулярную АГТ: 232 обследованных в Иваново, и 245 - в Саратове. Сравнительный анализ продемонстрировал значимые различия между пациентами двух регионов по основным характеристикам (пол, возраст и другие; табл. 2). Обратило на себя внимание то, что клиническое АД у пациентов обеих групп в среднем достигало целевых значений и даже было близко к оптимальному, особенно, у обследованных в Иваново (табл. 2). 
Table 4. Phenotypes and levels of BP in patients examined in Saratov in winter and in summer $(n=245)$ *

Таблица 4. Фенотипы и показатели АД зимой и летом у пациентов, обследованных в Саратове $(n=245)$ *

\begin{tabular}{|c|c|c|c|c|}
\hline Index / Показатель & $\begin{array}{l}\text { Controlled } \\
\text { hypertension } \\
\text { Эффективная АГТ }\end{array}$ & $\begin{array}{l}\text { Masked uncontrolled } \\
\text { hypertension } \\
\text { Скрытая } \\
\text { неэффективность АГт }\end{array}$ & $\begin{array}{l}\text { Uncontrolled } \\
\text { hypertension } \\
\text { Неэффективная } \\
\text { АГТ }\end{array}$ & $\begin{array}{l}\text { WCH in treated } \\
\text { patients } \\
\text { ГБХ на лечении }\end{array}$ \\
\hline \multicolumn{5}{|c|}{ Winter / Зима } \\
\hline$n(\%)$ & $62(25.3 \%)$ & $79(32.2 \%)$ & $95(38.8 \%)$ & $9(3.7 \%)$ \\
\hline Clinic BP, mm Hg / Клиническое АД, мм рт.ст. & $121.6 \pm 11.0 / 71.6 \pm 7.91$ & $125.3 \pm 9.4 / 75.4 \pm 7.9$ & $150.7 \pm 10.7 / 86.7 \pm 9.7$ & $143.2 \pm 5.5 / 81.4 \pm 6.3$ \\
\hline 24-hour BP, mm Hg / АД24, мм рт.ст & $117.2 \pm 6.6 / 71.1 \pm 4.2$ & $130.1 \pm 8.6 / 81.2 \pm 6.1$ & $140.0 \pm 12.9 / 84.0 \pm 8.0$ & $120.1 \pm 5.0 / 72.9 \pm 6.2$ \\
\hline Day ВP, mm Hg / АДдень, мм рт.ст. & $120.2 \pm 7.2 / 73.7 \pm 5.0$ & $132.3 \pm 9.6 / 83.4 \pm 6.7$ & $143.6 \pm 12.9 / 86.7 \pm 8.4$ & $124.0 \pm 6.4 / 76.1 \pm 6.5$ \\
\hline Night BP, mm Hg / АДночь, мм рт.Ст & $107.0 \pm 7.5 / 62.9 \pm 4.7$ & $121.6 \pm 10.8 / 73.8 \pm 7.6$ & $128.6 \pm 16.8 / 75.3 \pm 9.6$ & $106.6 \pm 6.7 / 61.9 \pm 5.3$ \\
\hline \multicolumn{5}{|c|}{ Summer / Лето } \\
\hline$n(\%)$ & $51(20.8 \%)$ & $123(50.2 \%)$ & $68(27.8 \%)$ & $3(1.2 \%)$ \\
\hline Clinic BP, mm Hg / Клиническое АД, мм рт.ст. & $115.7 \pm 10.4 / 68.4 \pm 8.4$ & $123.8 \pm 10.1 / 74.3 \pm 8.2$ & $148.4 \pm 8.4 / 84.7 \pm 10.2$ & $148.8 \pm 6.8 / 83.3 \pm 5.3$ \\
\hline 24-hour BP, mm Hg / АД24, мм рт.ст & $116.9 \pm 6.5 / 71.1 \pm 4.4$ & $129.4 \pm 9.7 / 81.6 \pm 6.5$ & $139.4 \pm 11.4 / 85.1 \pm 8.5$ & $114.4 \pm 10.1 / 73.0 \pm 1.7$ \\
\hline Day ВP, mm Hg / АДдень, мм рт.ст. & $119.6 \pm 7.4 / 73.4 \pm 5.2$ & $130.7 \pm 10.4 / 83.1 \pm 7.1$ & $141.2 \pm 11.3 / 86.9 \pm 9.1$ & $117.4 \pm 9.8 / 75.6 \pm 1.1$ \\
\hline Night BP, mm Hg / АДночь, мм рт.ст. & $107.7 \pm 6.6 / 63.2 \pm 4.5$ & $123.8 \pm 11.9 / 76.2 \pm 7.5$ & $132.2 \pm 13.7 / 78.3 \pm 8.6$ & $106.2 \pm 12.0 / 65.5 \pm 5.8$ \\
\hline \multicolumn{5}{|c|}{$\begin{array}{l}\text { Data are presented as } M \pm S D \text {, unless indicated otherwise } \\
\text { *Distinctions in rates of phenotypes in winter and in summer are significant }\left(\chi^{2}=18.127 ; p<0.0001\right) \\
\text { Rates of masked uncontrolled hypertension and average } B P \text { readings exceeding target levels are highlighted in bold }\end{array}$} \\
\hline $\begin{array}{l}\text { Данные представлены в процентах и M } \pm S D \text {, если не } \\
\text { *Различия в частоте фенотипов зимой и летом значи } \\
\text { Жирным шрифтом выделены процент пациентов со }\end{array}$ & $3,127 ; p<0,0001)$ & & & \\
\hline
\end{tabular}

Analysis of BP phenotypes in the patients examined in Ivanovo had demonstrated that about $90 \%$ of the patients in winter season and more than $90 \%$ in summer had target clinic BP level under regular antihypertensive treatment ( $<140$ and $90 \mathrm{~mm} \mathrm{Hg}$ ). However, more than two-thirds of them were referred to the "masked uncontrolled hypertension" phenotype both in winter and in summer: incidence rates of this phenotype equaled $62.1 \%$ of all the examined in Ivanovo in winter and $63.8 \%$ - in summer (Table 3 ). AHT was effective in $27.6 \%$ of patients of Ivanovo in winter and in $29.7 \%$ - in summer.

Clinic BP was increased in about $10 \%$ of the patients examined in Ivanovo with rates of WCH under treatment less than $1 \%$ in both seasons. AHT was ineffective in $9.5 \%$ of the patients in winter and in $6 \%$ - in summer. Significant distinctions in BP phenotypes prevalence in winter and summer seasons in the patients examined in Ivanovo were absent $\left(\chi^{2}=2.354\right.$; $\mathrm{p}>0.5$ )

The number of patients with target clinic BP level in Saratov was less than this in Ivanovo: $57.5 \%$ in winter and $71 \%$ - in summer; masked uncontrolled hypertension was revealed in more than a half of them in winter and in $70 \%$ in summer. Overall, $32.2 \%$ of the patients examined in Saratov revealed masked uncontrolled hypertension in winter and $50.2 \%$ - in summer (Table 4).

Statistically significant rise of the number of patients with this BP phenotype in summer time was followed
Анализ фенотипов АД пациентов, обследованных в Иваново, продемонстрировал, что около 90\% в зимний период и более $90 \%$ пациентов летом имеют целевые значения клинического АД на фоне регулярной АГТ (менее 140 и 90 мм рт.ст.). Однако более 2 /3 из них, как зимой, так и летом, относятся к фенотипу «скрытая неэффективность лечения АГ», частота которого составила $62,1 \%$ по отношению ко всем обследованным в Иваново зимой и 63,8\% - летом (табл. 3). Получали эффективную АГТ 27,6\% пациентов зимой, и 29,7\% - летом.

Повышенное клиническое АД отмечено примерно у 10\% пациентов, обследованных в Иваново, среди которых ГБХ на лечении встречалась менее чем у $1 \%$ в оба сезона. Неэффективной АГ была в зимний период у 9,5\% и у 6,0\% пациентов летом. Достоверных различий в соотношении фенотипов АД в зимний и летний периоды у обследованных в Иваново не было $\left(\chi^{2}=2,354 ; p>0,5\right)$.

В Саратове количество пациентов с целевым уровнем клинического АД было меньше, чем в Иваново, 57,5\% зимой и 71,0\% летом; среди них более половины зимой и 70\% летом имели скрытую неэффективность лечения АГ. В целом, среди обследованных в Саратове, частота скрытой неэффективности лечения составила 32,2\% зимой и 50,2\% летом (табл. 4). Достоверный рост числа пациентов с этим фенотипом АД в летний период сопровождался снижением числа пациентов с «явной» неэффективностью лечения АГ.

Повышенное клиническое АД зарегистрировано у 42,5\% пациентов Саратова зимой и у 29,0\% - летом. Подавляющее большинство этих больных получали неэффективную 
Table 5. Mean number of antihypertensive drugs per one patient in winter and in summer seasons

Таблица 5. Среднее количество антигипертензивных препаратов у одного пациента в зимний и летний периоды

\begin{tabular}{|lccc|}
\hline Region / Регион & Winter / Зима & Summer / Лето & $p$ \\
\hline Patients of Ivanovo / Пациенты Иваново & $1.5 \pm 0.7$ & $1.4 \pm 0.6$ & 0.329 \\
\hline Patients of Saratov / Пациенты Саратова & $1.8 \pm 1.0$ & $1.8 \pm 0.9$ & 0.835 \\
\hline$p$ & $>0.05$ & 0.001 & - \\
\hline
\end{tabular}

by reduction in the number of patients with "overt" uncontrolled hypertension.

$42.5 \%$ of the patients of Saratov revealed in creased clinic BP in winter and $29.0 \%$ - in summer. The vast majority of these patients received ineffective AHT: $38.8 \%$ of the total number of the examined patients in winter and $27.8 \%$ - in summer. Incidence rates of WCH in treated patients was rather low so as in Ivanovo and amounted to $3.7 \%$ in winter and $1.2 \%$ in summer. Seasonal changes in BP phenotypes prevalence in the hypertensive patients examined in Saratov was statistically significant $\left(\chi^{2}=18.127 ; p<0.0001\right)$.

We have found no significant distinctions in a number of antihypertensive drugs per one patient both between winter and summer seasons and between the groups of patients of the two cities (Table 5)

\section{Discussion}

The work has demonstrated rather high incidence rates of masked uncontrolled hypertension in patients with achieved target clinic BP level both in winter and in summer time, especially in the relatively colder RF region (Ivanovo) - 90-95\%; in the patients of the warmer region (Saratov) the rates were $56 \%$ and $71 \%$ in winter and summer, respectively. By indicating these figures, we specially place the emphasis on outpatients with achieved target clinic BP level. Achievement of target clinic BP level is obviously a certain success in hypertensive patient treatment, however, in case of masked uncontrolled hypertension target clinic BP level only creates invalid impression of AHT good response and favorable patient's prognosis as ambulatory BP level keeps being elevated. Ambulatory BP level had already many years ago been shown to be better predictor for cardiovascular complications as compared to clinic BP readings $[24,25]$. This was confirmed by prospective studies dealt with estimation of outcomes in patients with different BP phenotypes risk of myocardial infarction, stroke, lethal outcomes and other cardiovascular complications was significantly higher in masked uncontrolled hypertension as compared to normotension and well controlled hypertension and was similar to cardiovascular risk in sustained hypertension [7,26-29]. For instance, in accordance to Satoh M. et al. data [29] (with mean follow-up of 17.1 years) the risk of stroke in masked un-
АГТ - 38,8\% зимой и 27,8\% летом. Процент пациентов с ГБХ на лечении был, как и в Иваново, весьма мал и составлял 3,7\% и 1,2\% зимой и летом, соответственно. Сезонная динамика фенотипов АД у больных АГ, обследованных в Саратове, была достоверной $\left(\chi^{2}=18,127 ; p<0,0001\right)$.

Анализ среднего количества антигипертензивных препаратов на одного пациента в зимний и летний периоды не выявил значимых различий как между сезонами, так и между группами пациентов двух городов (табл. 5).

\section{Обсуждение}

Представленное в статье исследование показало среди пациентов с достигнутым целевым клиническим АД весьма большую частоту скрытой неэффективности лечения АГ как в зимний, так и летний период, особенно, в относительно более холодном регионе РФ (Иваново) - 90-95\%; у пациентов более теплого региона (Саратов) - 56\% зимой и около 71\% летом. Приводя эти цифры, мы специально акцентируем внимание на амбулаторных пациентах с достигнутым целевым клиническим АД. Безусловно, достижение целевого клинического АД - это определенный успех в лечении больного АГ, однако при скрытой неэффективности АГТ целевой уровень клинического АД (а в данном исследовании - уровень, близкий к оптимальному) лишь создает ложное впечатление о хорошем эффекте АГТ и позитивном прогнозе пациента, поскольку уровень амбулаторного АД остается повышенным. Уже много лет назад был доказан факт, что амбулаторное АД - лучший предиктор сердечно-сосудистых осложнений по сравнению с показателями клинических измерений $[24,25]$. Это подтверждают и проспективные исследования, посвященные оценке исходов при разных фенотипах АД, риск инфаркта миокарда, мозгового инсульта, летальных исходов и других сердечно-сосудистых осложнений при скрытой АГ значимо выше, чем при нормотонии и эффективной АГ, а также сопоставим с риском при устойчивой АГ [7, 26-29]. Например, в исследовании Satoh М. и соавт. [29] (средний период наблюдения 17,1 года) риск инсульта при скрытой АГ составил 2,05-2,08 (1,36-3,43), при устойчивой АГ - 2,46 (1,61-3,77), а при ГБХ - 1,38 $(0,82-2,32)$.

Представляется, что недостаточный учет фенотипа скрытой АГ вносит вклад в показатели сердечно-сосудистой заболеваемости и смертности, сохраняющиеся высокими, несмотря на улучшение контроля АГ на популяционном уровне в целом. Аналогично, недостаточный учет 
controlled hypertension was 2.05-2.08 (1.36-3.43), in sustained hypertension $-2.46(1.61-3.77)$ and in $\mathrm{WCH}-1.38$ (0.82-2.32).

Insufficient account for the "masked uncontrolled hypertension" phenotype is possibly contributes to cardiovascular morbidity and mortality rates which are kept high despite improvement in BP control at population level in whole. It is possible that insufficient account for seasonal changes in ambulatory BP and in BP phenotypes can similarly result in seasonal variability of cardiovascular diseases and complications including that one in patients under AHT. This can be illustrated by the following example. In accordance with our study data the mean daytime diastolic BP (DBP) level in the Ivanovo patients $(n=232)$ was higher in winter than in summer $(83.7 \pm 8.5 \mathrm{~mm} \mathrm{Hg}$ and $81.5 \pm 9.0$ $\mathrm{mm} \mathrm{Hg}$, respectively; $p<0.01$ ). In accordance with the other study data index of exceeded cardiovascular morbidity in winter season was $77.2 \%$ in the same region in 2009-2013 years, which included $30.5 \%$ of myocardial infarction morbidity rate [20]. However, this example is only relevant to seasonal changes in ambulatory BP level as we have found no significant seasonal variability in $\mathrm{BP}$ phenotypes prevalence in the presented sample of patients examined in Ivanovo.

Significant increase in the "masked uncontrolled hypertension" phenotype was revealed in summer season in the patients examined in the wormer region Saratov city (Table 4). This was due to rise in the number of patients with increased BP in summer season, especially, with increased nighttime BP (by $72.7 \%$ ). In whole, DBP in the patients examined in Saratov was lower in winter $(71.2 \pm 9.5 \mathrm{~mm} \mathrm{Hg})$ than in summer $(74.0 \pm 9.3 \mathrm{~mm} \mathrm{Hg} ; \mathrm{p}<0.01)$, which may be due to less comfortable night ambient temperatures in the region with hot summer. A number of patients with increased day BP in summer had been raised in a lesser degree - by $46.7 \%$. Increased nighttime ambulatory BP in summer (beyond the BP phenotypes question) had also been reported in Modesti et al. works $[11,12]$. This fact must be taken into account at AHT estimation. Such patients obviously need in correction of their nighttime BP with help of both medicated and non-drug measures (for example, climate control and air conditioning systems use). Absence of seasonal changes in BP phenotypes prevalence in the cohort of patients examined in Ivanovo was possibly due to the particularities of the sample - this cohort was younger than the patients of Saratov not only in real age but also had shorter history of hypertension, their clinic $\mathrm{BP}$ was on an average significantly lower. At the same time individual analysis (analysis of BP phenotypes reproducibility) had demonstrated the "controlled hypertension" phenotype to have the most stability: сезонных колебаний амбулаторного АД и сезонной динамики фенотипов АД, по-видимому, может обуславливать и сезонную вариабельность сердечно-сосудистых заболеваний и осложнений, в том числе у больных, получающих АГТ. В качестве условного обоснования можно привести следующий факт: в представленном исследовании средний уровень амбулаторного ДАД в дневные часы у пациентов, обследованных в Иваново $(n=232)$, зимой был

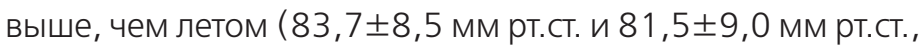
соответственно; $p<0,01)$. И в этом же регионе, по данным другого исследования, индекс избыточной заболеваемости сердечно-сосудистыми заболеваниями в зимний период составлял за 2009-2013 гг. 77,2\%, в том числе инфарктом миокарда - 30,5\% [20]. Однако в данном обосновании речь идет о сезонной динамике только амбулаторного АД, поскольку в представленной выборке пациентов не было значимой сезонной динамики фенотипов АД.

Достоверное увеличение фенотипа со скрытой неэффективностью лечения АГ в нашем исследовании отмечено в летний период среди пациентов, обследованных в более жарком регионе - Саратове (табл. 4). Это было связано с ростом летом числа пациентов с повышенным уровнем АД, преимущественно, в ночной период (на 72,7\%). В целом у пациентов, обследованных в Са-

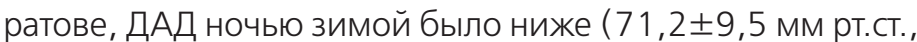

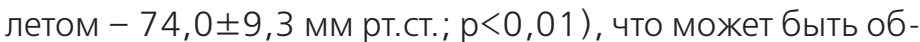
условлено более некомфортными ночными температурами окружающей среды в регионе с жарким летом. Количество пациентов с повышенным дневным АД летом возросло меньше - на 46,7\%. Повышенные значения амбулаторного АД летом в ночной период (вне аспекта фенотипов АД) описаны и в работах Modesti и соавт. $[11,12]$. Данный факт необходимо учитывать при оценке АГТ. Очевидно, что в жаркое время года таким пациентам необходима коррекция ночного АД с учетом как медикаментозных, так и немедикаментозных факторов (например, рекомендовать использование систем контроля «климата» внутри помещений, кондиционеров). Отсутствие сезонной динамики фенотипов АД в когорте пациентов, обследованных в Иваново, по-видимому, связано с особенностями выборки - эта когорта моложе пациентов, обследованных в Саратове не только по фактическому возрасту, но и по "стажу» АГ, их клиническое АД, в среднем, значимо ниже. В то же время, индивидуальный анализ (анализ воспроизводимости фенотипа АД) демонстрирует, что наибольшей устойчивостью обладает фенотип с оптимальным эффектом АГТ: 63,1\% и 80,0\% пациентов с таким фенотипом в Иваново и в Саратове, соответственно. Поскольку воспроизводимость фенотипа со скрытой неэффективностью лечения АГ в обеих выборках составляет около 40\%, очевидно, что динамика этого фенотипа существует в обеих когортах и, главным образом, из скрытой в «явную» неэффективность 
$63.1 \%$ and $80.0 \%$ of patients with this phenotype in Ivanovo and Saratov, respectively. As reproducibility of the "masked uncontrolled hypertension" phenotype was about $40 \%$ in both samples it is obvious that changes in this phenotype prevalence was presented in both cohorts, in the first place there was conversion of masked uncontrolled hypertension in evidently uncontrolled one and inversely, as long as patients with $\mathrm{WCH}$ were in small numbers in our study.

Incidence rates of the "masked uncontrolled hypertension" phenotype in both samples of our study (Tables 3 and 4) were in whole comparable with other studies data $[5-8,30]$. However these studies estimated BP phenotypes without reference to season. We have found no works devoted to separate estimation of one or another BP phenotype in summer and winter seasons in such resources as PubMed, Scopus and Web of Science.

The main limitations of the study were relatively small samples and distinctions between the cohorts of patients in some initial characteristics.

Improvement of hypertension treatment is one of the main health care resources focused on lowering of cardiovascular morbidity and mortality. Management of hypertension with regard to seasonal BP variability and BP phenotypes is a prospective strategy. This article presents both approaches to the problem in their interrelation. Ascertainment of BP phenotype by combined evaluation of clinic and ambulatory BP levels is of great importance. If a patient reveals high $B P$ at visit to a doctor, he, as a rule, takes in account possibility of WCH and tries to estimate level of ambulatory BP, while in case of normal clinic BP level a doctor does not always draw attention to assessment of ambulatory BP level which can often be increased. We should remind that in accordance with contemporary guidelines patients with masked uncontrolled hypertension (masked hypertension in treated patients) as a rule need in change of AHT [3]. Focused detection and correction of masked uncontrolled hypertension must be an integral part of management of patients received AHT. BP phenotype ascertainment and reckoning with seasonal factors interrelated with $\mathrm{BP}$ is a personal approach to hypertensive patient management aimed at cardiovascular risk reduction. At the same time evaluation of factors associated with "unfavorable" $\mathrm{BP}$ phenotypes in patients received AHT is necessary, this will be presented in the second part of our work.

\section{Conclusion}

Ratio of BP phenotypes in different samples of hypertensive patients with clinic BP $<160 / 100 \mathrm{~mm} \mathrm{Hg}$ under treatment differs in winter and summer seasons. In our study the cohort of younger patients in a rel-
АГТ, и наоборот, так как пациентов с ГБХ на лечении было немного.

Частота фенотипа со скрытой неэффективностью лечения АГ в целом, в обеих выборках представленной работы (табл. 3 и 4) сопоставима с данными других исследований [5-8,30], правда, в них фенотипы АД изучались без взаимосвязи с сезоном; работ, в которых частота того или иного фенотипа АД изучалась бы отдельно в летний и зимний периоды, на ресурсах PubMed, Scopus, Web of Science нам найти не удалось.

Основные ограничения представленного исследования - относительно небольшая выборка, а также различия между когортами пациентов двух регионов по некоторым исходным характеристикам.

Совершенствование лечения АГ - один из главных ресурсов здравоохранения, направленных на снижение сердечно-сосудистой заболеваемости и смертности. Перспективным является подход к контролю лечения АГ с учетом сезонной вариабельности АД и с позиций фенотипов АД. Два этих подхода к проблеме представлены в этой статье в их взаимосвязи. Определение фенотипа АД путем совместной оценки показателей клинического и амбулаторного АД чрезвычайно важно: если АД на визите к врачу у пациента повышено то, как правило, врач учитывает возможность ГБХ и старается оценить уровень амбулаторного АД. В случае же нормальных показателей клинического АД врач не всегда акцентирует внимание на оценке значений амбулаторного АД, а оно зачастую может быть повышенным. Напомним, что, согласно современным рекомендациям пациенты со скрытой неэффективностью лечения АГ (masked uncontrolled hypertension или masked hypertension in treated patients), как правило, нуждаются в изменении АГТ [3]. Целенаправленное выявление и коррекция скрытой неэффективности лечения АГ по современным представлениям должны быть неотьемлемой частью ведения пациентов, получающих АГТ. Индивидуальный подход к ведению больного АГ с целью снижения риска сердечно-сосудистых осложнений - оценка фенотипа АД и учет сезонных факторов, взаимосвязанных с АД. В то же время необходима оценка факторов, ассоциированных с «проблемными» фенотипами АД у больных, получающих АГТ, и эта оценка будет представлена во второй части нашей работы.

\section{Заключение}

В разных выборках больных АГ с клиническим АД<160/100 мм рт.ст. на фоне АГТ соотношение фенотипов АД в зимний и летний периоды отличается. В нашем исследовании в когорте пациентов относительно более молодого возраста в относительно холодном регионе отсутствовала выраженная сезонная динамика фенотипов АД, и преобладал фенотип со скрытой неэффективностью лечения АГ (>60\%). В когорте пациентов более старшего возраста с бо́льшим «стажем» АГ, обследованных в более теп- 
atively cold region has not revealed significant seasonal variability in BP phenotypes and demonstrated prevalence of the "masked uncontrolled hypertension" phenotype $(>60 \%)$. The cohort of older patients with longer hypertension history examined in a wormer region revealed significantly higher incidence rate of masked uncontrolled hypertension in summer (50.2\%) while other phenotypes prevailed in winter. However further evaluation of this problem is necessary, in the first place detection of potential markers of masked uncontrolled hypertension.

Conflict of interest. All of the authors declare the absence of potential conflict of interest which needs to be disclosed in this article.

\section{Acknowledgement}

The authors of the article acknowledge the following colleagues who participated in the study: Andreeva G.F.1, Belova O.A.2, Dovgalevsky P.Ya. ${ }^{3}$, Dolotovskaya P.V. ${ }^{3}$, Kravcova E.A. ${ }^{2}$, Nazarova O.A. ${ }^{2}$, Platonova E.V. ${ }^{1}$, Puchinyan N.Ph. ${ }^{3}$, Rachkova S.A. ${ }^{2}$, Romanchuk S.V.2, Sokolova N.S.2, Furman N.V. ${ }^{3}$.

${ }^{1}$ National Medical Research Center for Preventive Medicine.

2Ivanovo Regional Cardiology Clinic

3Saratov Research Institute of Cardiology лом регионе, частота скрытой неэффективности лечения АГ значимо выше была летом (50,2\%), частота остальных фенотипов - зимой. Однако нужны дальнейшие исследования данной проблемы, в первую очередь, выявление факторов - потенциальных маркеров скрытой неэффективности лечения АГ.

Конфликт интересов. Все авторы заявляют об отсутствии потенциального конфликта интересов, требующего раскрытия в данной статье.

\section{Благодарности}

Авторы статьи выражают свою признательность коллегам, участвовавшим в проведении исследования: Андреевой Г.Ф.1, Беловой О.А.2, Довгалевскому П.Я.3, Долотовской П.В.3, Кравцовой Е.А.2, Назаровой О.А. ${ }^{2}$, Платоновой Е.В. ${ }^{1}$, Пучиньяну Н.Ф. ${ }^{3}$, Рачковой С.А. ${ }^{2}$, Романчук С.В.2 , Соколовой Н.С. ${ }^{2}$, Фурману Н.В. ${ }^{3}$

1 Национальный медицинский исследовательский центр профилактической медицины.

2Кардиологический диспансер г. Иваново.

${ }^{3}$ Саратовский научно-исследовательский институт кардиологии.

\section{References / Литература}

1. Kaplan N.M. New Issues in the Treatment of Isolated Systolic Hypertension Circulation. 2000;102:107981. doi:10.1161/01.CIR.102.10.1079.

2. Viera A.J., Shimbo D. Ambulatory Blood Pressure Phenotypes and the Risk for Hypertension Curr Hypertens Rep. 2014;16(10):481. doi:10.1007/s11906-014-0481-5.

3. 2013 ESH/ESC Guidelines for the management of arterial hypertension. The Task Force for the management of arterial hypertension of the European Society of Hypertension (ESH) and of the European Society of Cardiology (ESC). Eur Heart J. 2013;34:2159-219. doi: 10.1093/eurheartj/eht151.

4. 2013 Ambulatory Blood Pressure Monitoring Recommendations for the Diagnosis of Adult Hypertension, Assessment of Cardiovascular and other Hypertension-associated Risk, and Attainment of Therapeutic Goals. Chronobiology International. 2013;30(3):355-410. doi: 10.3109/07420528.2013.750490.

5. Smirnova M.I., Oganov R.G., Gorbunov V.M. The hidden ineffectiveness of treatment of arterial hypertension: frequency and predictors. Cardiovascular Therapy and Prevention. 2011;10(6):11-7. (In Russ.) [Смирнова М.И., Оганов Р.Г., Горбунов В.М. и др. Скрытая неэффективность лечения артериальной гипертонии: частота и предикторы. Кардиоваскулярная Терапия и Профилактика. 2011;10(6):11-7]

6. Smirnova M.I., Platonova E.M., Britov A.N., et al. The rate and characters of masked arterial hypertension and masked ineffectiveness of hypertension treatment in industrial workers according to the preventive examination. Rational Pharmacotherapy in Cardiology. 2014;10(5):481-7. (In Russ.) [Смирнова М.И., Платонова Е.М., Бритов А.Н. и др. Частота и маркеры скрытой артериальной гипертонии и скрытой незффективности лечения артериальной гипертонии у работников промышленного предприятия по данным профилактического осмотра. Рациональная Фармакотерапия в Кардиологии. 2014;10(5):481-7]. doi: 10.20996/1819-6446-2014-10-5-481-487.

7. Stergiou G.S., Asayama K., Thijs L., et al. Prognosis of white coat and masked hypertension: International Database of HOme blood pressure in relation to Cardiovascular Outcome. Hypertension. 2014:63(4):675-82. doi: 10.1161/HYPERTENSIONAHA.113.02741.

8. Banegas J.R., Ruilope L.M., de la Sierra A., et al. High prevalence of masked uncontrolled hypertension in people with treated hypertension. Eur Heart J. 2014;35(46):3304-12. doi: 10.1093/eurheartj/ehu016.

9. Brook R.D., Weder A.B., Rajagopalan S. "Environmental hypertensionology" the effects of environmental factors on blood pressure in clinical practice and research. J Clin Hypertens (Greenwich). 2011;13:836842. doi: 10.1111/j.1751-7176.2011.00543.x.

10. Sega R., Cesana G., Bombelli M. et al. Seasonal variations in home and ambulatory blood pressure in the PAMELA population. J Hypertens. 1998;16:1585-92.
11. Modesti P.A., Morabito M., Bertolozzi I. et al. Weather-related changes in 24-hour blood pressure profile. Effects of age and implications for hypertension management. Hypertension. 2006;47:155-61. doi: 10.1161/01.HYP.0000199192.17126.d4.

12. Modesti P.A., Morabito M., Massetti L. et al. Seasonal blood pressure changes: an independent relationship with temperature and daylight hours. Hypertension. 2013;61(4):908-14. doi: 10.1161/HYPERTENSIONAHA.111.00315

13. Smirnova M.I., Gorbunov V.M., Volkov D.A. Seasonal changes in hemodynamic parameters in patients with controlled arterial hypertension and high normal arterial pressure in two regions of the Russian Federation with different climatic characteristics. Part 3. Main results of the study of 1630 patients. Profilakticheskaya Meditsina. 2015;6:78-86. (In Russ.) [Смирнова М.И., Горбунов В.М., Волков Д.А. и др. Сезонные изменения гемодинамических параметров у больных с контролируемой артериальной гипертонией и высоким нормальным артериальным давлением в двух регионах Российской Федерации с различными климатическими характеристиками. Часть 3. Основные результаты исследования 1630 пациентов. Профилактическая Медицина. 2015;6:78-86] doi:10.17116/profmed201518678-86

14. Boulay F., Berthier F., Sisteron O. et al. Seasonal variation in chronic heart failure hospitalizations and mortality in France. Circulation. 1999;100:280-6. doi: 10.1161/01.CIR.100.3.280/

15. Dilaveris P., Synetos A., Giannopoulos G., et al. CLimate Impacts on Myocardial infarction deaths in the Athens TErritory: the CLIMATE study. Heart. 2006;92:1747-51. doi: 10.1136/hrt.2006.091884/

16. Fomina N.V., Altarev S.S., Barbarash O.L. Annual biological rhythms as an additional risk factor for death in patients with ischemic heart disease. Circulation Pathology and Surgery. 2007;(1):44-7. (In Russ.) [Фомина Н.В., Алтарев С.С., Барбараш О.Л. Годовые биологические ритмы как дополнительный фактор риска смерти при ишемической болезни сердца. Патология Кровообращения и Кардиохирургия. 2007; (1):44-7].

17. Rocklöv J., Forsberg B. The effect of temperature on mortality in Stockholm 1998-2003: A study of lag structures and heatwave effects. Scandinav J Pub Health. 2008;36:516-23. doi: $10.1177 / 1403494807088458$.

18. Revich B.A., Shaposhnikov D.A. Extreme temperature episodes and mortality in Yakutsk, East Siberia. Rural and Remote Health. 2010;10:1338.

19. Kontsevaya A.V., Lukyanov M.M., Khudyakov M.B. Seasonal and monthly changes of mortality in Russian Federation regions with different climate and geographic variables. Rossiyskiy Kardiologicheskiy Zhurnal. 2014;11:25-30. (In Russ.) [Концевая А.В., Лукьянов М.М., Худяков М.Б. Сезонные и помесячные изменения смертности в регионах Российский Федерации с различными климато-географическими характеристиками. Российский Кардиологический Журнал. 2014;11:2530]. doi: 10.15829/1560-4071-2014-11-25-30. 
20. Kontsevaya A.V., Balanova J.A., Loukianov M.M., Khudyakov M.B., Belova O.A., Romanchuk S.V. Excess winter cardiovascular morbidity in Ivanovo Region in 2009-2013 years. Rational Pharmacotherapy in Cardiology. 2015;1 (5):450-8. (In Russ.) [Концевая А.В., Баланова Ю.А., Лукьянов М.М., Худяков М.Б., Белова О.А., Романчук С.В. Избыточная заболеваемость сердечно-сосудистыми заболеваниями в зимний период в Ивановской области в 2009-2013 г. Рациональная Фармакотерапия в Кардиологии. 2015;11 (5):450-8. doi:10.20996/1819-6446-2015-11-5-450-458.

21. Kontsevaia A.V., Lukyanov M.M., Balanova lu.A. et al. Social and economic burden caused by excess winter cardiovascular deaths in the Russian Federation"s regions with different climatic and geographic characteristics. Profilakticheskaya Meditsina. 2014;6:21-5. (In Russ.) [Концевая А.В., Лукьянов М.М., Баланова Ю.А. идр. Социально-экономический ущерб, вызванный избыточной смертностью от сердечно-сосудистых заболеваний в зимний период в регионах Российской Федерации с различными климато-географическими характеристиками. Профилактическая Медицина. 2014;6:21-5]

22. Smirnova M.I., Gorbunov V.M., Boytsov S.A. Seasonal changes in hemodynamic parameters in patients with controlled arterial hypertension and high normal arterial pressure in two regions of the Russian Federation with different climatic characteristics. Part 1. Design and preliminary results. Profilakticheskaya Meditsina. 2013;6:71-8. (In Russ.) [Смирнова М.И., Горбунов В.М., Бойцов С.А. и др. Сезонные изменения гемодинамических параметров у больных с контролируемой артериальной гипертонией и высоким нормальным артериальным давлением в двух регионах Российской Федерации с различными климатическими характеристиками. Часть 1. Дизайн и предварительные результаты. Профилактическая Медицина. 2013;6:71-8].

23. Diagnosis and treatment of hypertension. National clinical recommendations. Sistemnye Gipertenzii. 2010; 3: 5-26. (In Russ.) [Диагностика и лечение артериальной гипертензии. Национальные клинические рекомендации. Системные Гипертензии. 2010; 3: 5-26].

\section{About the Authors:}

Marina I. Smirnova - MD, PhD, Leading Researcher, Laboratory of Outpatient Diagnostic Methods in the Prevention of Chronic Non-Communicable Diseases, National Medical Research Center for Preventive Medicine

Vladimir M. Gorbunov - MD, PhD, Professor, Head of Laboratory of Outpatient Diagnostic Methods in the Prevention of Chronic Non-Communicable Diseases, National Medical Research Center for Preventive Medicine

Sergey A. Boytsov - MD, PhD, Professor, Corresponding Member of the Russian Academy of Sciences, General Director, National Medical Research Center for Cardiology

Michail M. Loukianov - MD, PhD, Leading Researcher, Department of Clinical Cardiology and Molecular Genetics, National Medical Research Center for Preventive Medicine

Anna M. Kalinina - MD, PhD, Professor, Department of Primary Prevention of Chronic Non-Communicable Diseases in the Healthcare System, National Medical Research Center for Preventive Medicine Dmitriy A. Volkov - MD, Junior Research, Laboratory of Outpatient Diagnostic Methods in the Prevention of Chronic Non-Communicable Diseases, National Medical Research Center for Preventive Medicine

Alexander D. Deev - PhD (in Physics and Mathematics), Head of Laboratory of Biostatistics, National Medical Research Center for Preventive Medicine

Yana N. Koshelyaevskaya - Programmer, Laboratory of Outpatient Diagnostic Methods in the Prevention of Chronic Non-Communicable Diseases, National Medical Research Center for Preventive Medicine Ekaterina N. Belova - Programmer, Laboratory of Biostatistics, National Medical Research Center for Preventive Medicine
24. Perloff D., Sokolow M., Cowan R. The prognostic value of ambulatory blood pressures. JAMA. 1983;249:2792-8. doi:10.1001/jama.1983.03330440030027.

25. Dolan E., Stanton A., Thijs L., et al. Superiority of ambulatory over clinic blood pressure measurement in predicting mortality. The Dublin outcome study. Hypertension. 2005; 46: 156-161. doi: 10.1161/01.HYP.0000170138.56903.7a.

26. Pierdominico S.D., Cuccurillo F. Prognostic value of white coat and masked hypertension diagnosed by ambulatory monitoring in initially untreated subjects: an update meta-analysis. Am J Hypertens. 2011; 24:52-8. doi: 10.1038/ajh.2010.203.

27. Grassi G., Mancia G. The PAMELA study - results and perspectives. Council for Cardiology Practice. 2011; 10(5). Available at: https://www.escardio.org/Journals/E-Journal-of-Cardiology-Practice/Volume-10/The-PAMELA-study-results-and-perspectives. Checked by Sep 16, 2017.

28. Bobrie G., Clerson P., Menard J. et al. Masked hypertension: a systematic review. J Hypertens. 2008,26:1715-25. doi: 10.1097/HJH.0b013e3282fbcedf.

29. Satoh M., Asayama K., Kikuya M. et al. Long-Term Stroke Risk Due to Partial White Coat or Masked Hypertension Based on Home and Ambulatory Blood Pressure Measurements. The Ohasama Study. Hypertension. 2016;67:48-55. doi: 10.1161/HYPERTENSIONAHA.115.06461.

30. Ishikava J., Kario K., Equchi K. et al. Regular alcohol drinking is a determinant of masked morning hypertension detected by home blood pressure monitoring in medicated hypertensive patients with wellcontrolled clinic blood pressure: the Jichi Morning Hypertension Research (J-MORE) study. Hypertens Res. 2006;29:679-86. doi: 10.1291/hypres.29.679

\author{
Сведения об авторах: \\ Смирнова Марина Игоревна - К.м.н., В.н.С. лаборатории \\ применения амбулаторных диагностических методов \\ в профилактике хронических неинфекционных заболеваний, \\ НМИЦ ПМ
}

Горбунов Владимир Михайлович - д.м.Н., профессор, руководитель лаборатории применения амбулаторных диагностических методов в профилактике хронических неинфекционных заболеваний, НМИЦ ПМ

Бойцов Сергей Анатольевич - д.м.н., профессор, член-корреспондент РАН, генеральный директор НМИЦ кардиологии

Лукьянов Михаил Михайлович - К.М.Н., В.Н.С. отдела клинической кардиологии и молекулярной генетики, НМИЦ ПМ Калинина Анна Михайловна - д.м.н., профессор, руководитель отдела первичной профилактики хронических неинфекционных заболеваний в системе здравоохранения, НМИЦ ПМ Волков Дмитрий Александрович - М.н.С. лаборатории применения амбулаторных диагностических методов в профилактике хронических неинфекционных заболеваний, НМИЦ ПМ

Деев Александр Дмитриевич - к.ф. -М.н., руководитель лаборатории биостатистики, НМИЦ ПМ Кошеляевская Яна Николаевна - программист лаборатории применения амбулаторных диагностических методов в профилактике хронических неинфекционных заболеваний, НМИЦ ПМ

Белова Екатерина Николаевна - программист лаборатории биостатистики, НМИЦПМ 